\title{
Shattering the Glass Ceiling: Ensuring the Right to Vote for Persons with Intellectual Disabilities In Kenya
}

\author{
Lawrence Murugu Mute
}

\author{
Kenya National Commission on Human Rights \\ Imute@knchr.org OR lamumu07@gmail.com
}

\author{
Thought and Practice: A Journal of the Philosophical Association of Kenya (PAK) \\ New Series, Vol.2 No.2, December 2010, pp.1-18 \\ thoughtandpractice@gmail.com OR thoughtandpractice@uonbi.ac.ke \\ http://ajol.info/index.php/tp/index
}

\begin{abstract}
Is it self-evident that every Kenyan adult citizen should have the right to vote at national and civic elections or referenda? This is not always the case: certain segments of the population are expressly or implicitly excluded by law or practice from the franchise. This paper suggests that the concept of unsoundness of mind should no longer be the basis for excluding persons with disabilities generally, and those with intellectual disabilities in particular, from voting. It traces provisions in law that disenfranchise persons adjudged to be of unsound mind; and provides interpretation using national law as well as international human rights norms to infer that general or automatic disenfranchisement is a human rights violation. It concludes that Kenya's electoral authorities must ensure that neither their policies nor the practices of their officials disenfranchise some Kenyan adults from voting by equating such persons' mental illness or intellectual disabilities with "unsoundness of mind".
\end{abstract}

\section{Key Words}

Mental illness; intellectual disabilities; unsound mind; law; human rights 


\section{Glossary of Abbreviations}

CoE: Committee of Experts on Constitutional Review.

CRPD: Convention on the Rights of Persons with Disabilities.

IIEC: Interim Independent Electoral Commission.

PSC: Parliamentary Select Committee.

\section{Introduction}

The Constitution of Kenya (Republic 2010b) was promulgated on 27th August 2010 following its overwhelming acceptance by voters during the referendum of 4th August of that year. The long road to that Constitution throws up interesting nuances regarding the extent to which persons with intellectual disabilities in Kenya may participate in public elections either as voters or as candidates.

Article 83(1) of the Kenyan Constitution provides that:

A person qualifies for registration as a voter at elections or referenda if the person- (a) is an adult citizen; (b) is not declared to be of unsound mind; and (c) has not been convicted of an election offence during the preceding five years.

This provision is in line with Section 43(2) of the Former Constitution (Republic 2008a), which disqualified from registration as a voter any person adjudged or declared to be of unsound mind "under any law in force" (paragraph A). Other classes of persons similarly excluded from registration as voters were persons who were undischarged bankrupts, and those detained in lawful custody. 
Both the 2004 Draft Constitution of Kenya ("the Bomas Draft") and the 2005 Proposed Constitution of Kenya ("the Wako Draft") 1 eschewed exclusion through Constitutional provision. They did not disqualify any classes of Kenyan citizens from the franchise, both merely stating that Parliament could make provisions for other necessary qualifications (Republic 2004, Article 103(1); Republic 2005, Article 104). Nevertheless, both Drafts specifically provided that certain classes of persons may not stand for elective office: Article 124(2) of the "Bomas Draft" and Article 117(2) of the "Wako Draft" provided that a person of unsound mind is disqualified from being elected a Member of Parliament.

When the most recent constitutional review exercise commenced in 2008, the approach in the earlier Drafts prevailed for a while. Thus neither the Harmonised Draft Constitution released by the Committee of Experts on Constitutional Review (CoE) on 17th November 2009 (Republic 2009), nor the Revised Harmonised Draft Constitution presented by the CoE to the Parliamentary Select Committee on Constitutional Review (PSC) on 8th January 2010 (Republic 2010a) specifically excluded any class of Kenyan adults from voting, merely anticipating that Parliament would make further provisions in relation to qualifications: in effect statutory rather than constitutional provisions would determine whether or not, and the extent to which, Kenyan adults might be prevented from voting. It was the Parliamentary Select Committee (PSC) on Constitutional Review whose revisions introduced specific constitutional provisions to disenfranchise certain classes of Kenyans. Subsequently, the Constitution promulgated on 27th August 2010 included the provisions in Article 83(1) as cited above.

During the constitutional referendum campaign in 2010, the Interim Independent Electoral Commission (IIEC) sent mixed signals on whether persons with mental illnesses or intellectual disabilities would be registered as voters for purposes of the referendum on the Proposed Constitution. In a public address on the 24th of March 2010, IIEC's Chief Executive Officer reportedly said:

\footnotetext{
${ }^{1}$ The Bomas Draft Constitution was negotiated by a multi-stakeholder assembly at Bomas of Kenya in 2003 and 2004. The Wako Draft was prepared by the Government when it rejected the Bomas Draft, and the Wako Draft itself was in turn rejected at a national referendum in 2005.
} 
Voter registration and the act of voting means exercising discretion. Exercising discretion after considering all the relevant factors is a very intellectual exercise and perhaps if you are mentally impaired, you may not be able to exercise that capacity to use the vote. 2

A month later, the Chief Executive was far more positive when he urged guardians of those with physical or mental impairments to encourage the persons with disabilities with whom they worked to register as voters:

There are about 3.6 million people with mental disabilities but what do you do with that number? .... How do you make the world realise that you are there? The only way to do that is to be a contributor in the major decision making process in your country ... let as make sure that at least a half of those with disabilities are registered (Wambui 2010).

Of more relevance to future elections is the policy approaches which state agencies - the Executive, the Legislature, the Judiciary and Constitutional Offices - ought to use for purposes of interpreting Article 83(1) of the Constitution from a human rights perspective. Unravelling this conundrum which could continue to disenfranchise many persons with disabilities calls for answers to the following questions:

- Who is a person of unsound mind?

- What is the interface between mental illness, intellectual disability and being of unsound mind?

- Should persons with mental illnesses or intellectual disabilities be disenfranchised?

- Does Kenyan law forbid persons with disabilities from being registered as voters?

- If not, what realities undermine the letter of the law?

\footnotetext{
${ }^{2}$ Text as aired on 24th March 2010 on the 9 p.m. news, cited in letter of 25th March, 2010 from the Kenya Society for the Mentally Handicapped written to the Chief Executive Officer of the IIEC (on file with author).
} 
- What steps should Kenya's electoral body take to guarantee the franchise of all Kenyan adults?

\section{Intellectual Disability, Unsoundness of Mind, and Mental Illness}

Intellectual disability is characterised by significant limitations in intellectual functioning and adaptive behaviour covering everyday social and practical skills. Limitations in intellectual functioning relate to activities such as learning, reasoning and problem solving. Limitations in adaptive behaviour relate to three types of skills:

- Conceptual skills: language and literacy, money, time and number concepts, etc.

- Social skills: inter-personal skills, self-esteem, gullibility, etc.

- Practical skills: daily living skills, safety, use of money, etc. ${ }^{3}$

Being of unsound mind is a far more limited concept with legal as well as medical purports. At the legal level, this is a judicially determined term describing unsound, diseased, or deranged mental functioning (Mosby's Medical Dictionary, 2009). Courts have defined the phrase "unsound mind" variously. One judge stated:

An unsound mind exists where there is an essential privation of the reasoning faculties, or where a person is incapable of understanding and acting with discretion in the ordinary affairs of life. 4

The Virginia Supreme Court approved an 'irresistible impulse' definition of unsound mind. At one end is the idea that anyone who commits suicide is mentally ill and therefore is of unsound mind. At the other end is the idea that only those persons attempting suicide who meet the determination of legal insanity are of unsound mind.5

\footnotetext{
3 This characterization is drawn from http:/www.aaidd.org/content 100.cfm?navID=21 (accessed on 16th February 2011)

${ }^{4}$ Turner v. Howerton et al., no. 22689-VA, April 2, 1997

${ }^{5}$ Molchon v. Tyler, 546 S.E.2d 691, 695 (Va. 2001)
} 
At the medical level, there is a close nexus between mental illness and being of unsound mind. Mental illness is a medical condition which ought to be determined by medical professionals and not legislators and judges. What the law does recognize is that mental illness may have various legal effects. A mentally ill individual is one "having a psychiatric or other disease which substantially impairs his (or her) mental health" (Draft Act Governing Hospitalization Of The Mentally Ill, 1952). The Wisconsin Mental Health Act simply states that "Mental illness is synonymous with insanity".6

For purposes of this paper, a person is of unsound mind only when he or she has been so declared by a judicial process. Section 162 of Kenya's Criminal Procedure Code, Cap. 63 (Republic 2008b), provides that a court may inquire as to and determine whether a person is of unsound mind. On the other hand, being of unsound mind describes a state of mental ill health which is determinable only by medical professionals, hence the Mental Health Act, Cap 248 (Republic 1993), which among other things establishes the framework for receiving and treating persons with mental disorders in mental hospitals. The bulk of persons with intellectual disabilities therefore are technically not unsound of mind; and indeed, as the rest of this paper shows, even if they were adjudged to be of unsound mind, fundamental rights still accrue to them.

The question, then, is whether or not mental ill health may on occasion translate into disability. The Convention on the Rights of Persons with Disabilities (CRPD) (United Nations 2006), which Kenya signed and ratified in 2007 and 2008 respectively, recognises that disability “... results from the interaction between persons with impairments and attitudinal and environmental barriers that hinders their full and effective participation in society on an equal basis with others" (Preamble); and that "persons with disabilities include those who have long-term physical, mental, intellectual or sensory impairments which in interaction with various barriers may hinder their full and effective participation in society on an equal basis with others" (Article 1).

\footnotetext{
${ }^{6}$ Wis. Stat. § $\mathbf{5 0 . 0 0 1}(1957)$
} 
Hence illness in and of itself may not be a disability. Nevertheless, if a person's organ (in this case the mind) is so impaired as to undermine such person's long-term effective interaction with his or her surroundings (social, economic, political, etc.), then that individual has a disability. This point may seem to be merely academic, but in fact it is not. If the law after declaring a person to be of unsound mind proceeds to disenfranchise him or her, that is discrimination on the ground of disability.

\section{Why Persons with Intellectual Disabilities are Disenfranchised}

Various reasons have over the centuries been used to justify excluding persons with intellectual disabilities from electoral processes.

One formula, referred to as the "status approach", assumed by law that a person merely on account of having an intellectual disability had no legal capacity, that is, he or she had no personhood; and that an entity or someone else would make decisions for him or her - what is referred to as "substituted decision-making". The tendency under this model was to disregard the will and preferences of the individual with an intellectual disability, even where this was clearly detectable (Quinn 2010). Today this approach is epitomised by guardianship laws pursuant to which decision-making of a person with an intellectual disability is substituted by that of another person. Thus the Mental Health Act (Republic 1993) empowers a court to make orders for the management of the estate of a person "suffering from mental disorder" (Section 26(1)(a)), and for the guardianship of such person (paragraph (b)).

Even more influential (albeit erroneous) to shaping thinking regarding elections was the socalled "outcomes approach". This approach determined that a person with an intellectual disability had no legal capacity on the ground of the bad decisions, or pattern of bad decisions, or by the flawed process of decision-making of that individual (Quinn 2010). The assumption was that persons with intellectual disabilities had no capability of understanding the electoral process, and would therefore be prone to manipulation (Spinelli 2007). This indeed is the basis upon which laws over time prejudged the capacity of persons with intellectual disabilities, for example, denying them the franchise. 
Writing about the legal restrictions applied to persons with intellectual disabilities in relation to the vote, Lewis notes:

... The assumption is that mad people will cast irrational votes. It hilariously follows therefore that people without labels of mental disorders/disabilities cast rational votes. What is rationality anyway? Since when have people without labels of mental disorders/disabilities had to take a rationality test at the polling station? What would such a test look like? And since when did we discount irrational votes? If we think racism is irrational, did we discount those votes which were cast solely because of the ethnicity of the candidates? Doesn't rationality in voting boil down to agreement with the person who is conducting the rationality test, just like consenting to medical treatment boils down to agreeing with the doctor? (Lewis 2009).

The outcomes approach is no longer advanced with any seriousness. After all, "non-disabled" electorates keep choosing "bad" leaders. Nevertheless, denial of legal capacity for persons with intellectual disabilities remained on the statute books, taking away entitlements such as to vote, to stand for elective office, to join political parties, and even the right to work (Lewis 2009). Different countries apply various approaches in this regard. In South Africa, only a court can find a citizen to be of unsound mind, and certification to that effect is duly issued to the electoral agency, which consequently disqualifies such a person from voting. In New Zealand, only persons compulsorily detained in a hospital or secure facility with appropriate judicial orders are disenfranchised. In the United Kingdom, even patients detained in mental institutions may temporarily leave so as to vote or they may vote by post or by proxy. Some countries - Canada, Sweden, Italy and Ireland - do not place any restrictions on voters with intellectual disabilities (Ace Electoral Knowledge Network 2011). 


\section{Does Kenyan Law Disenfranchise Persons with Intellectual Disabilities?}

When responding to this question, one needs to approach Kenyan legislation with a mind to undertake incisive dissection of nuance, rather than dwelling on accepted norms and assumptions informing current practice in the bar and on the bench. Two questions arise:

- Is an individual with an intellectual disability entitled to vote?

- If so, is such an individual entitled to be assisted by a person of his or her choice to vote?

\section{Entitlement to vote as an element of legal capacity}

Article 83(1) of the Kenyan Constitution (Republic 2010b) has already been cited here as disqualifying from registration as a voter any person adjudged or declared to be of unsound mind under Kenyan law. Several matters may be raised here.

First, interpreting this constitutional provision needs to take account of the already-made clarification that persons of unsound mind should not be necessarily equated with persons with intellectual disabilities or persons with mental illnesses. This is due to the fact that being of unsound mind is a technical construction determined by a court of law, and applies only to those individuals with mental illnesses or intellectual disabilities who have been through a medical or judicial process respectively. In the absence of a formal judicial or medical determination, one cannot be said to be of unsound mind.

Second, the National Presidential and Parliamentary Elections Act, Cap. 7 (Republic 2007) provides greater room for seeking a better understanding of franchise issues. That statute empowers Kenya's electoral body to make regulations to, among other things, "Provide for the manner in which an elector who is blind or otherwise incapacitated may vote or be assisted in voting" (Section 34(1)(o)). Regulations made pursuant to this provision proceed on that basis. Regulation 23(1) of the Presidential and Parliamentary Elections Regulations states: “... an elector who is blind or otherwise incapacitated may vote or be assisted in voting”; and Regulation 26 provides: “... this regulation shall not prevent the companion of a 
blind or incapacitated elector from communicating with that elector". Of relevance here is whether the phrase "or incapacitated" should be understood only with reference to a "blind" person, or whether that phrase should be taken to cover other types of disabilities, in which case, a further question relates to whether such disability is only physical or sensory and excludes mental incapacity.

Third, there is the Persons with Disabilities Act, Act No. 14 of 2003 (Republic 2003), which in Section 29(1) provides that "All persons with disabilities shall be entitled at their request, to be assisted by persons of their choice in voting in presidential, parliamentary and civic elections". It defines disability as "a physical, sensory, mental or other impairment, including any visual, hearing, learning or physical incapability, which impacts adversely on social, economic or environmental participation" (Section 2).7 The contention here is that Section 34(1)(o) of the National Presidential and Parliamentary Elections Act read together with the Persons with Disabilities Act surely could not have intended to protect the franchise only of persons with sensory or physical disabilities, and that the law sought to protect all categories of persons with disabilities, in line with Section 29 of the Persons with Disabilities Act, whose protection relates to "all" persons with disabilities. 8 Furthermore, Article 27 of the Constitution specifically provides that the state shall not discriminate a person on account of his or her disability.

The above interpretation would be backed by the conscious decision which the State took in 2007 and 2008 respectively when it signed and ratified the Convention on the Rights of Persons with Disabilities (CRPD) (United Nations 2006). Article 12 of that Convention affirms three standards at the heart of this discussion.

First, persons with disabilities have the right to recognition everywhere as persons before the law (paragraph 1). This is an affirmation that disability does not deprive a person of his or her personhood. Second, persons with disabilities enjoy legal capacity on an equal basis with

\footnotetext{
${ }^{7}$ The situation is rather muddied by the fact that the Persons with Disabilities Act refers to "incapability" instead of "incapacity", which is the reference in the National Presidential and Parliamentary Elections Act.

${ }^{8}$ Also see section below on mediating capacity to act.
} 
others in all aspects of life (paragraph 2): that legal capacity does not stop inhering in a person because of his or her disability, and such enjoyment relates to all aspects of the lives of such individuals. 9 The third standard is discussed under the next sub-heading.

\section{Mediating capacity to act}

The second moot question relates to whether persons with intellectual disabilities can be 'assisted' as necessary so that they may vote. Article 12 paragraph 3 of the CRPD provides that "States parties shall take appropriate measures to provide access by persons with disabilities to the support they may require in exercising their legal capacity." The Convention recognizes that while all persons have legal capacity in spite of their descriptions, specific circumstances of disability may mean that a person may have lesser possibility of acting on his or her own in exercise of his or her legal capacity; and that appropriate support (with appropriate and effective safeguards: Paragraph 4) should be provided in such cases.10

Kenyan law has recently developed in relation to persons with intellectual disabilities with the affirmation in statute of the concept of the "intermediary". Section 31 of the Sexual Offenses Act, Act No. 3 of 2006 (Republic 2006) provides, inter alia, that the court may declare as a "vulnerable witness" a witness with a mental disability or a person likely to be vulnerable among others on account of intellectual, psychological or physical impairment. Such a vulnerable witness may use an intermediary while giving his or her evidence. The question, then, is this: if judicial processes already anticipate the possibility of mediation

\footnotetext{
${ }^{9}$ Article 29 of the Convention buttresses this position in its provision that "States Parties shall guarantee to persons with disabilities political rights and the opportunity to enjoy them on an equal basis with others, and shall undertake to: (a) Ensure that persons with disabilities can effectively and fully participate in political and public life on an equal basis with others ... including the right and opportunity for persons with disabilities to vote and be elected, inter alia, by: (i) Ensuring that voting procedures, facilities and materials are appropriate, accessible and easy to understand and use; (ii) Protecting the right of persons with disabilities to vote by secret ballot in elections and public referendums without intimidation, and to stand for elections, to effectively hold office and perform all public functions at all levels of government, facilitating the use of assistive and new technologies where appropriate; (iii) Guaranteeing the free expression of the will of persons with disabilities as electors and to this end, where necessary, at their request, allowing assistance in voting by a person of their own choice ...."

${ }^{10}$ This is in line with Article 25 of the International Covenant on Civil and Political Rights, which provides that "every citizen shall have the right and the opportunity, without any of the distinctions mentioned in Article 2 and without unreasonable restrictions: (a) to take part in the conduct of public affairs, directly or through freely chosen representatives; (b) to vote and to be elected at genuine periodic elections."
} 
between a court and a person with an intellectual disability, why should the electoral system not make similar anticipations? ${ }^{11}$

Regarding disabilities generally, a broad interpretation of Sections 29 and 30 of the Persons with Disabilities Act (Republic 2003) would have the following effects. Upon their request, they would be entitled to assisters of their choice to enable them to vote. Assisters would include a reader (for a voter with a visual impairment), a sign language interpreter (for a deaf voter), or an intermediary (for a voter with an intellectual disability). Similar results could be drawn from Section 30:

Polling stations shall be made accessible to persons with disabilities during elections, and such persons shall in addition be provided with the necessary devices and assistive devices and services to facilitate the exercise of this right under this section.

Assistive devices and services would include the services listed above.

One further matter may be addressed here. Those who argue against the enfranchisement of persons with certain types of disabilities justify their position on the basis that such enfranchisement will merely lead to abuse of the vote by such electors' assisters, for example by disregarding the voting intentions of a person with a disability. Nevertheless, Article 12(4) of the CRPD clarifies that appropriate safeguards to protect against such eventualities must be put in place. In this regard, it is worth considering the fact that the state protects its citizens

${ }^{11}$ Yet, Kenyan courts still remain unprepared to make landmark rulings in relation to the right to vote for persons of unsound mind. A landmark ruling preceding last year's referendum, the case of Priscilla Nyokabi Kanyua v. AG, Constitutional Petition No. 1 of 2010, enfranchised persons incarcerated in prison to be rightful participants in the referendum. At the same time though, the court noted that: "A person who is in prison and is of unsound mind is not in control of his faculties and may not be able to know the magnitude of any election let alone the referendum. The exclusion of that class of inmates is therefore obvious and self explanatory." 
against street crime, but it does not force civilians off the streets. Similarly, rather than disenfranchise persons with disabilities because of the danger of abuse, the state should protect against such abuse; but any protective measures must respect the rights, will and preferences of the person. Kenyan electoral law in part recognises this when it stipulates that an assister is criminally liable if he or she discloses the way in which the person he or she assisted voted.

\section{Enfranchising Persons with Disabilities in Kenya: Tripple Messages}

Last year's promulgation of a new Constitution as Kenya's new grand-norm might be seen as a bane rather than a boon for persons with intellectual disabilities: it indeed would have been far better if the Constitution had left it to Parliament to legislate on any necessary disqualifications, instead of it (the Constitution) disenfranchising "persons of unsound mind". Nonetheless, several messages may be gleaned from the foregoing discussion.

First, the key message for Kenya's electoral body is that it should enforce the letter of the law upon itself and all its agencies. As has been set out in the foregoing discussion, the only persons who the electoral agency could stop from voting by law today are those adjudged as of unsound mind, and no register of such persons by law is required to be availed to the elections agency. In past national and local elections, presiding officers at polling stations have reportedly declined to allow voters with intellectual disabilities from participating in polls. However, it is not clear what tests such officers have employed to determine the disability of such voters. The electoral body should instruct its officials not to use traits of a voter such as their demeanour or mannerisms to conclude that they are of unsound mind and that they should be barred from voting at elections or referenda. It is therefore commendable that prior to the 2010 constitutional referendum, the IIEC reportedly established a voter registration centre at the offices of the Kenya Society for the Mentally Handicapped (Wambui 2010).

Second, in spite of the provisions in Article 83(1) of the Kenyan Constitution, all is not lost. The Constitution includes multiple provisions which may and indeed shall be the basis in due 
course for ensuring and protecting the vote of all persons with disabilities. Stakeholders must fervently advocate for legislative interventions and judicial interpretation to attain this end. Relevant key provisions in the Constitution that will aid this effort include the following:

- Article 55(2), which compares favourably with Article 29 of the CRPD.12 It provides that:

The State shall ensure the progressive implementation of the principle that at least five percent of the members of the public in elective and appointive bodies are persons with disabilities.

- In the same vein, Article 38(3) provides that:

Every adult citizen has the right, without unreasonable restrictions, - (a) to be registered as a voter; (b) to vote by secret ballot in any election or referendum; and (c) to be a candidate for public office, or office within a political party of which the citizen is a member and, if elected, to hold office.

- Other provisions in the Constitution confirm that international human rights law and principles will be part of or will be used to construe Kenyan law. Article 2(5) provides that "The general rules of international law shall form part of the law of Kenya." Furthermore, Article 2(6) establishes a landmark in Kenya's legal framework by turning the country from a dualist into a monist state. It provides that "Any treaty or convention ratified by Kenya shall form part of the law of Kenya under this Constitution." Subsequently, Article 21(1) obligates the State to "enact and implement legislation to fulfil its international obligations in respect of human rights and fundamental freedoms." Finally, the President under Article 131(2)(e) shall "ensure the protection of human rights and fundamental freedoms and the rule of law."

Third, the key message for civil society and human rights organizations which advocate for the rights of persons with intellectual disabilities is that they should not take advantage of legal limitations to make impractical or unreasonable demands of state agencies. Instead, they should engage the electoral body so that its officials may have the best instruction and

\footnotetext{
${ }^{12}$ See supra footnote 9
} 
awareness regarding the distinctions that this paper has pointed out and the actions which it has proposed. They should also raise awareness amongst the public to enable a more objective understanding regarding the importance of the vote for persons with intellectual disabilities. The fiction that "sane" electors make rational decisions and that "mad" ones do not should also be imploded. Besides, emphasis should be laid on voter education for persons with intellectual disabilities, with focus on individualised voter education when and as necessary. 13

\section{Conclusion: Shattered Glass}

The weight of expectation on the Committee on the Rights of Persons with Disabilities, established by Article 35 of the Convention on the Rights of Persons with Disabilities (CRPD) (United Nations 2006) to monitor implementation of the Convention, is immense. Article 12 of the Convention has introduced norms which require bold yet careful interpretation. It will not be good enough for the Committee to shred the script of conservatism, which dominates thinking on the legal capacity of persons with intellectual disabilities, if it does not script proposals that are sound from a human rights viewpoint. Its proposals must also be capable of acceptability and implementation by states, as they are the basic duty bearers under the Convention. What is more, the Committee must not be held hostage by the fundamentalist activism of some groups within the disability movement which want all their rights now! Rather, it must explore and reshape the sort of humdrum thinking articulated by the Human Rights Committee when it notes:

The exercise of ... (the right to vote) by citizens may not be suspended or excluded except on grounds which are established by law and which are objective and reasonable. For example, established mental incapacity may be a ground for denying a person the right to vote or to hold office (Human Rights Committee, General Comment No. 25, paragraph 4).

\footnotetext{
${ }^{13}$ Article 24(2)(e) of the CRPD acknowledges that maximization of the social development of persons with disabilities may entail use of individualized education measures, but always focusing on the goal of full inclusion of such persons into society.
} 
One more essential note must be made here. It is a common adage that "Every village has its mad man". Yet if the residents of a village chose to elevate their "mad-man" to be their chief, would there be anything essentially wrong in that? In other words, if the villagers were so mad they crowned a madman their leader, what objective test of sanity (rationality) could the law use to invalidate that? With what legitimacy? Why, then, does the law forbid persons of unsound mind from standing for elective office? Is Kenya so "mad" it would actually elect them, and if so, are our leaders not as good (or bad) as the electors who choose them? If Kenya then is a mental asylum, does one citizen have the right to point an accusing finger at another citizen?

Many scripts in this discourse remain unwritten. Kenya must be at the heart of that scripting. The state participated wholesomely in negotiating the Convention on the Rights of Persons with Disabilities (CRPD). It should be at the heart of imploding myths and prejudices and thereby, by extension, implementing this landmark human rights instrument.

\section{References}

ACE Electoral knowledge network. 2011. "Definition of mental illness in Electoral law". http://aceproject.org/electoral-advice/archive/questions/replies/493785866

Draft Act Governing Hospitalization Of The Mentally Ill. U.S. Pub. Health Service Publication No. 51 (rev. ed. 1952).

Human Rights Committee. General Comment No. 25: Article 25 (participation in public affairs and the to vote). www.unhchr.ch/tbs/doc.../d0b7f023e8d6d9898025651e004bc0eb?...-

Lewis, Oliver. 2009. "How can Strategic Litigation Play a Role in Nudging States towards Legal Capacity Utopia?" A preliminary ideas paper for discussion on 13th November 2009 at the seminar on disability litigation in Washington DC, organized by the Mental Disability Rights International, the Open Society Institute and the American University.

Mosby's Medical Dictionary. 8th edition. (C) 2009. Elsevier. 
Quinn, Gerard. 2010. "Personhood and Legal Capacity: Perspectives on the Paradigm Shift of Article 12 of CRPD”. HPOD Conference. Harvard Law School. 20 February, 2010.

Republic of Kenya. 1993. Mental Health Act. Cap. 248. www.kenyalaw.org/kenyalaw/klr_app/frames.php

--. 2003. Persons with Disabilities Act, Act No.14 of 2003. www.kenyalaw.org/kenyalaw/klr_app/frames.php

--. 2004. Draft Constitution of Kenya. Adopted by the National Constitutional Conference on 15 March 2004. http://www.coekenya.go.ke/index.php?option=com_content\&view $=$ article\&id=53\&Itemid=6 5

--. $2005 . \quad$ Proposed Constitution $\quad$ Kenya. http://www.coekenya.go.ke/index.php?option=com content $\&$ view $=$ article $\& \mathrm{id}=53 \&$ Itemid $=6$ $\underline{5}$

--. 2006. Sexual Offenses Act. Act No. 3 of 2006. www.kenyalaw.org/kenyalaw/klr app/frames.php

--. 2007. National Presidential and Parliamentary Elections Act. Cap. 7. www.kenyalaw.org/kenyalaw/klr_app/frames.php

--. 2008a. Constitution of Kenya (repealed) Act. http://www.kenyalaw.org/kenyalaw/klr_app/frames.php

--. 2008b. Criminal Procedure 63. www.kenyalaw.org/kenyalaw/klr_app/frames.php -

--. 2009. Harmonised Draft Constitution of Kenya. Published on 17th November, 2009 by the Committee of Experts on Constitutional Review. http://www.coekenya.go.ke/index.php?option=com_content $\&$ view $=$ article \&id $=53 \&$ Itemid $=6$ $\underline{5}$ 
--. 2010a. Revised Harmonised Constitution of Kenya, as reviewed by the Committee of $\begin{array}{llll}\text { Experts } & \text { Constitutional Review. }\end{array}$ http://www.coekenya.go.ke/index.php?option=com_content\&view $=$ article $\& \mathrm{id}=53 \&$ Itemid $=6$ 5

--. 2010b. Constitution of Kenya Act. http://www.kenyalaw.org/kenyalaw/klr_app/frames.php Spinelli, Antonio. 2007. "Definition of mental illness in electoral law". http://aceproject.org/electoral-advice/archive/questions/replies/493785866

Wambui, Sarah. 2010. "Kenyan people with disabilities urged to register". 21 April 2010. http://www.butterfly.co.ke/bews/local/disabled-person-in-kenya-urged-to -register//152/23914/-/10oofxw/-/index.html

United Nations. 2006. Convention on the Rights of Persons with Disabilities. 2006. http://www.un.org/disabilities/convention/conventionfull.shtml 